\title{
Dissolved Cyclic Adenosine Monophosphate (cAMP) in the Sea and Uptake of cAMP by Marine Bacteria
}

\author{
J. W. Ammerman and F. Azam \\ Institute of Marine Resources, A-018, Scripps Institution of Oceanography, University of California, San Diego, La Jolla, \\ California 92093, USA
}

\begin{abstract}
Dissolved cyclic-3',5'-adenosine monophosphate (CAMP) was measured in coastal seawater. Concentrations of cAMP ranged from 1 to $35 \times 10^{-12} \mathrm{M}$ being greatest in nearshore surface samples and from early evening through early morning. Dissolved cAMP was rapidly taken up intact by natural populations of marine bacteria, evidently via high affinity transport systems. Much higher concentrations were found in sediments. Presumed sources of dissolved CAMP are planktonic organisms (bacteria, algae, zooplankton, etc.). cAMP was also measurable in the plankton. Uptake of cAMP from seawater apparently increases the intracellular concentration of cAMP in marine bacteria and thus may play a role in their metabolic regulation.
\end{abstract}

\section{INTRODUCTION}

Marine bacteria grow in an exceedingly dilute environment containing a myriad of individual, dissolved organic compounds present in concentrations from $10^{-7}$ to $10^{-13} \mathrm{M}$ (Williams, 1975). Most amino acids, sugars, and other compounds nutritionally important to the bacteria fall in the upper part of this concentration range while possible growth-regulating compounds, such as vitamins, generally occupy the lower part (Williams, 1975). Due to the extreme dilution of most of these compounds, however, relatively few measurements are presently available (Williams, 1975; Azam and Hodson, 1977; Daumas and Saliot, 1977; Morris and Eglinton, 1977; Mopper et al., 1980).

To further our understanding of the metabolism and growth of marine bacteria, seawater must be defined in terms of the compounds likely to be important both in bacterial nutrition and metabolic regulation. The purpose of the present study is to demonstrate that cyclic$3^{\prime}, 5^{\prime}$-adenosine monophosphate (CAMP), a compound with widespread regulatory roles in both procaryotic (Rickenberg, 1974) and eucaryotic cells (Pastan et al., 1975), occurs consistently in coastal seawater in dissolved form (DCAMP). We also describe the dynamics of the cAMP pool in seawater, particularly in relation to the uptake and accumulation of the compound by marine bacteria. The DcAMP concentration appears to be related to the in situ biological activity.

\section{MATERIALS AND METHODS}

We collected water samples for DcAMP analysis from several coastal locations. Surface seawater was frequently sampled from the pier of the Scripps Institution of Oceanography $\left(32^{\circ} 53^{\prime} \mathrm{N}, 117^{\circ} 15^{\prime} \mathrm{W}\right)$ with sterile flasks. Cleaned Niskin bottles were used to collect a series of samples from the surface to $500 \mathrm{~m}$ at a station $41 \mathrm{~km}$ offshore in the Southern California Bight $\left(32^{\circ}\right.$ $52^{\prime} \mathrm{N}, 117^{\circ} 38^{\prime} \mathrm{W}$; March 31, 1978). Samples were also taken at the Controlled Ecosystem Population Experiment (CEPEX) (Menzel and Case, 1977) site in Saanich Inlet, British Columbia, Canada $\left(48^{\circ} 40^{\prime} \mathrm{N}, 123^{\circ} 29^{\prime} \mathrm{W}\right)$. A $10 \mathrm{~m}$ diameter and $30 \mathrm{~m}$ deep water column $\left(1300 \mathrm{~m}^{2}\right)$ which had been enclosed for 2.5 months was sampled in integrated $4 \mathrm{~m}$ intervals from 0 to $20 \mathrm{~m}$ with a peristaltic pump (September 28, 1978).

To investigate the temporal variation of cAMP concentration in relation to the daily cycle of primary production, surface seawater was sampled periodically from Scripps Pier over a 24-h period (October 23-24, 1979). A sterile carboy was also filled with surface seawater at the start of the period and maintained in a 
shaded incubator with running seawater It was sampled concurrently. A similar experiment was performed at a station $5.6 \mathrm{~km}$ offshore in the Southern California Bight $\left(33^{\circ} 28^{\prime} \mathrm{N}, 117^{\circ} 47^{\prime} \mathrm{W}\right.$; August 26-27, 1979). A carboy was filled with water pumped from $20 \mathrm{~m}$ and was sampled as above.

Shortly after collection, the seawater samples were filtered through $0.45-\mu \mathrm{m}$ pore size Millipore filters (HA) and then frozen or analyzed immediately. Most samples were split into $200 \mathrm{ml}$ aliquots, and all were acidified to $0.6 \mathrm{~N}$ with sulfuric acid. Radioactive $\left(2,8-{ }^{3} \mathrm{H}\right)$-cAMP $(0.2 \mathrm{pmol}$ per sample) was added to each aliquot as an internal standard prior to passage through a column of activated charcoal (methods of Hodson et al., 1976). The columns were then rinsed with 10-20 $\mathrm{ml}$ of distilled water and eluted with $5 \mathrm{ml}$ of ethanol:water:ammonium hydroxide (50:50:1 v/v). One $\mathrm{ml}$ of each eluate was removed and radioassayed by liquid scintillation spectrometry to determine recovery from the column (usually about $60 \%$ ), and the remainder was dried in a vortex evaporator at $40^{\circ} \mathrm{C}$. Samples were then reconstituted in $0.3 \mathrm{ml}$ of sodium acetate buffer (50 mM, ph 6.2) and assayed for cAMP by radioimmunoassay (New England Nuclear Corp., Boston, Mass., USA).

Sediment samples (upper $10 \mathrm{~cm}$ ) were collected at several stations in the Southern California Bight with gravity cores or grab samplers. To measure DCAMP in sediment, about $2 \mathrm{ml}$ of freshly collected sediment was dispersed in $50 \mathrm{ml}$ sterile artificial seawater. This slurry was filtered through an HA filter and the filtrate treated as with seawater samples. For determination of CAMP in marine particulates, including plankton, 200 to $1000 \mathrm{ml}$ of seawater from Scripps Pier was filtered through an HA filter and the filter boiled for $5 \mathrm{~min}$ in sodium acetate buffer ( $50 \mathrm{mM}, \mathrm{pH} \mathrm{6.2)}$ or extracted in $0.6 \mathrm{~N}$ sulfuric acid. The extract was passed through a charcoal column, as above, or assayed directly.

To study uptake of DcAMP by natural populations of marine bacteria, $50 \mathrm{pM}\left(2,8-{ }^{3} \mathrm{H}\right)$-cAMP (final concentration) was added to water samples from a CEPEX enclosure and incubated at $15^{\circ} \mathrm{C}$ for $2 \mathrm{~h}$. Samples were then filtered through an HA filter, rinsed twice with filtered seawater, and the turnover rate in percent (Azam and Holm-Hansen, 1973) calculated from the radioactivity on the filters as: DPM taken up (100) $\mathrm{h}^{-1}$. (DPM originally added) ${ }^{-1}$. Samples were corrected for abiotic adsorption by subtracting the DPM from a parallel sample killed with $0.5 \mu \mathrm{M} \mathrm{HgCl}_{2}$ (final concentration). Five adsorption blanks averaged $7.2 \pm$ $3.6 \%$ (one standard deviation) of the total uptake. Cell numbers were determined by epifluorescence microscopy of acridine orange stained samples (Hobbie et al., 1977). Uptake rates per cell were then calculated from the equation: (cAMP) turnover rate (cell number) ${ }^{-1}$.
Similar experiments were performed to assess the onshore-offshore pattern of DCAMP pool turnover in the Southern California Bight. A series of $5 \mathrm{~m}$ samples were taken along a transect and $320 \mathrm{pM}\left(2,8{ }^{3} \mathrm{H}\right)$ CAMP was added to each and then treated as above.

\section{RESULTS AND DISCUSSION}

DCAMP was found in all samples examined, in nearshore and offshore waters, at concentrations varying with depth of sampling and distance from shore. DCAMP concentrations in surface seawater samples from Scripps Pier varied from 2 to $30 \mathrm{pM}$, though most ranged between 4 and $15 \mathrm{pM}$. Standard deviations of replicated samples typically ranged from 10 to $30 \%$ of the mean (e.g. $13.25 \pm 2.06$ pM, $n=5$ ). DcAMP concentrations in the relatively oligotrophic Southern California Bight were low at a station $41 \mathrm{~km}$ offshore with a bottom depth of about $1000 \mathrm{~m}$ (Fig. 1). DCAMP showed a subsurface maximum at about $50 \mathrm{~m}$ followed by a gradual decrease with depth, as previously observed for dissolved ATP by Azam and Hodson (1977). DCAMP concentration at $500 \mathrm{~m}$ was still about $40 \%$ of the sub-surface maximum although the planktonic biomass at $500 \mathrm{~m}$ should have been about 100

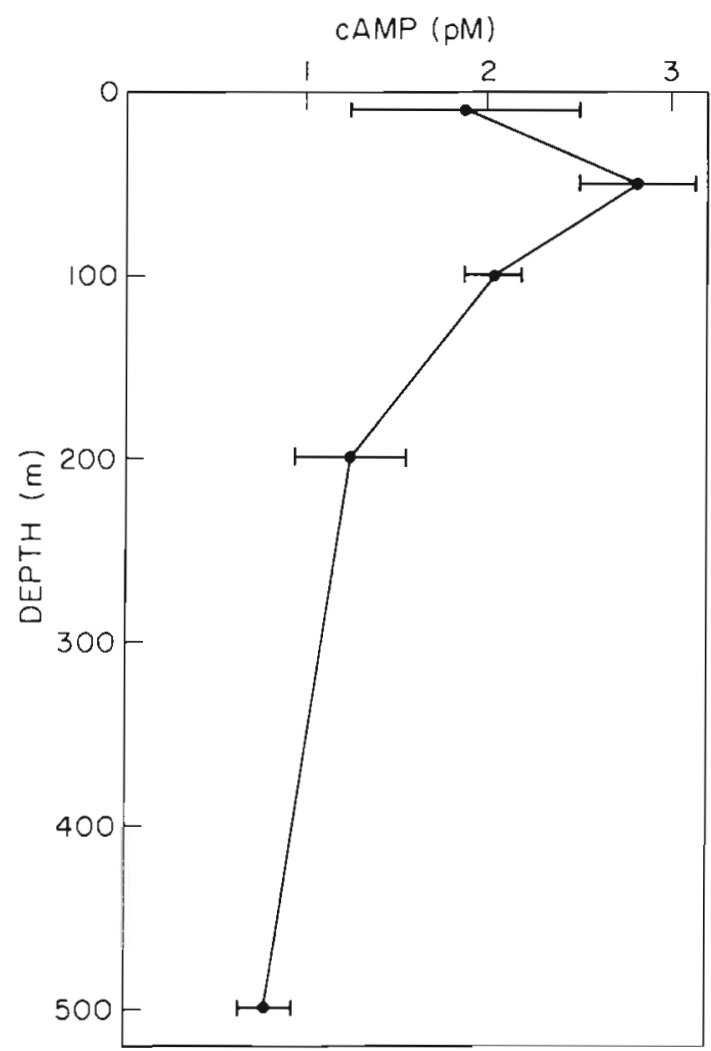

Fig. 1. Depth profile of DCAMP concentration at a station $41 \mathrm{~km}$ olfshore in Southern California Bight. Mean and range $(\mathrm{n}=2)$ are shown for each depth 
times less than at $50 \mathrm{~m}$ (Holm-Hansen, 1973). The general depth distribution pattern of DCAMP was similar to that of phytoplankton and bacteria over much of the Southern California Bight (Fuhrman et al., 1980). The $20 \mathrm{~m}$ DcAMP concentration (12 pM) at a closer station, $5.6 \mathrm{~km}$ offshore, was the same as for Scripps Pier surface samples. The DcAMP concentration in the upper $10 \mathrm{~m}$ of an enclosed water column in eutrophic Saanich Inlet, British Columbia, Canada, was three times higher than that found in Southern California waters, but decreased rapidly with depth (Fig. 2a).

The identity of the measured compound as cAMP was confirmed by treatment of column eluates with bovine heart 3',5'-cyclic nucleotide phosphodiesterase (E. C. No. 3.1.4.17), which specifically hydrolyzes CAMP and cyclic-3',5'-guanosine monophosphate (cGMP) (Butcher, 1974). Incubation for $1 \mathrm{~h}$ reduced the measured CAMP by $93 \%$; boiled (denatured) phosphodiesterase caused only a $10 \%$ decrease. Cyclic GMP cross-reactivity in the CAMP radioimmunoassay is typically less than $0.1 \%$ (Steiner, 1974).

To show that DCAMP was not an artifact of filtration, a cleaned sterile dialysis bag was filled with autoclaved distilled water and suspended from Scripps Pier for $24 \mathrm{~h}$. This was sufficient time for equilibration with seawater as determined by salinity measurements. Cyclic AMP analysis of the bag's contents (in two separate experiments) gave values comparable to filtered samples.

DCAMP concentrations in sediment samples from the Southern California Bight ranged from 90 to $3600 \mathrm{pM}$ (pmol $1^{-1}$ of sediment), with most values under $1000 \mathrm{pM}$. These are probably underestimates since some of the DCAMP in pore water may have been absorbed on sediment particles. Nevertheless, measured sediment concentrations of DCAMP were 1 to 3 orders of magnitude greater than in the water column, as is true of many other dissolved organic compounds (Mopper, 1977; Mopper et al., 1980).
In the 24-h experiment from Scripps Pier, DcAMP concentrations showed a fourfold diel variation in the surface water and a greater variation in the carboy (Fig. 3a). Results were similar for other carboys filled either at the pier (data not shown) or $5.6 \mathrm{~km}$ offshore (Fig. 3a); the peak in DCAMP always occurred between sunset and midnight. Because this peak did not occur in samples prefiltered through $1 \mu \mathrm{m}$ Nuclepore filters (data not shown) to remove algae but not bacteria (Azam and Hodson, 1977), enhanced algal excretion related to the onset of darkness may be responsible. This would be consistent with laboratory observations that cultured freshwater algae release cAMP into the medium at rates that may vary in response to environmental conditions (Francko and Wetzel, 1980). Neither algal or bacterial uptake of cAMP (see below) can account for the sharp drop in the concentration of this compound before dawn. Hydrolysis of DcAMP by cell surface phosphodiesterases might explain this decrease, however. In the Scripps Pier experiment shown (Fig. 3 b), CAMP in planktion peaked at the same time as DCAMP but was only $20 \%$ as high. More CAMP was found in plankton in other instances but rarely exceeded the concentration of the DCAMP.

DCAMP removal from seawater may be by chemical or enzymatic hydrolysis, or microbial uptake. Chemical stability of DCAMP was examined in filtersterilized $(0.22 \mu \mathrm{M}$ Millipore filter) and filtersterilized-autoclaved seawater. These samples were enriched to $160 \mathrm{pM} \mathrm{CAMP}$ and incubated at $18^{\circ} \mathrm{C}$ for $26 \mathrm{~h}$. The change in DCAMP in both samples was negligible, ruling out chemical hydrolysis or hydrolysis by enzymes dissolved in seawater as significant routes of DCAMP removal.

Natural populations of marine microorganisms readily took up $\left(2,8-{ }^{3} \mathrm{H}\right)$-or $\left({ }^{32} \mathrm{P}\right)$-CAMP. This uptake was predominately $(80 \%)$ by organisms passing $0.6 \mu \mathrm{m}$ Nuclepore filters, a fraction containing bacteria and some cyanobacteria (Azam and Hodson, 1977; Water-

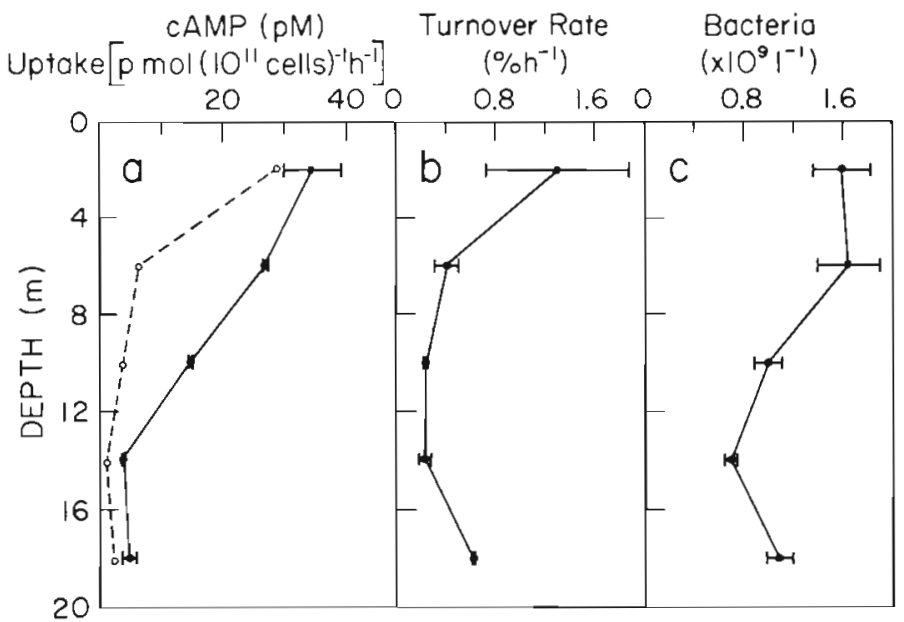

Fig. 2. Depth profiles in a CEPEX enclosure in Saanich Inlet, British Columbia, Canada (a) Solid profile, DCAMP concentration (mean and range, $n=2$ ); dashed profile, DCAMP uptake (mean values). (b) Turnover rate of DcAMP (mean and range, $\mathrm{n}=2$ ). (c) Average bacterial number July-September, 1978 (mean \pm standard error, $\mathrm{n}=25$ ) 


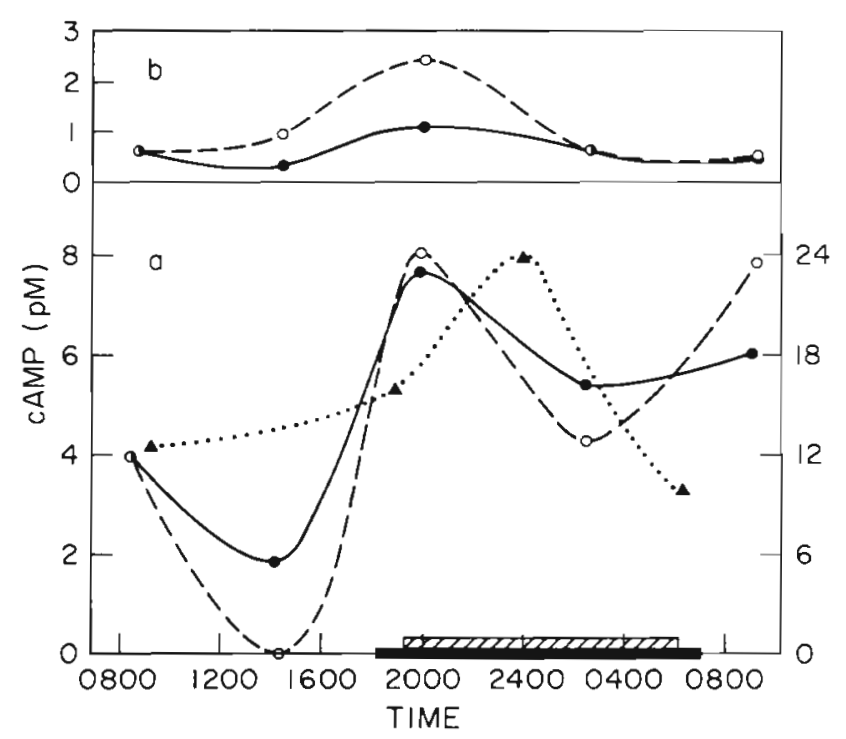

Fig. 3. Temporal variation in DCAMP concentrations in seawater and cAMP concentrations in marine particulates (a) DCAMP in surface seawater from Scripps pier $(\bullet$, left ordinate). DCAMP measured in Scripps pier surface seawater contained in a sterile carboy (O, left ordinate). Initial DCAMP concentration in carboy was assumed to be same as in surface seawater. Period between sunset and sunrise indicated by wide solid line on abscissa. DCAMP in a carboy filled with 20 $\mathrm{m}$ water from a station $5.6 \mathrm{~km}$ offshore in the Southern California Bight ( 1 , right ordinate). Sunset to sunrise indicated by diagonal hatching on abscissa. (b) CAMP in marine particulates. Symbols indicate the same source of samples as in (a)

bury et al., 1979). In the Southern California Bight, rapid rates of DCAMP pool turnover $\left(\approx 1 \% \mathrm{~h}^{-1}\right)$ within $6 \mathrm{~km}$ of shore decreased to $\approx 0.1 \% \mathrm{~h}^{-1}$ at $100 \mathrm{~km}$ offshore. Turnover rates were also high in an enclosed water column (CEPEX) in Saanich Inlet, British Columbia (Fig. 2b). DCAMP pool turnover rates there exceeded $1 \% \mathrm{~h}^{-1}$ in surface waters but decreased sharply with depth. Bacterial abundance (Fig. 2c) and bacterial activity (measured by incorporation of $\left({ }^{3} \mathrm{H}\right)$ thymidine (Fuhrman et al., 1980) or uptake of $\left({ }^{3} \mathrm{H}\right)$ glucose and leucine (Hollibaugh et al., 1980) showed onshore-offshore and depth profiles similar to those of DcAMP uptake. This suggests that DCAMP uptake is related to bacterial metabolism and growth.

In all bacteria studied, including marine species, cAMP plays a central role in the regulation of cell metabolism (Rickenberg, 1974; Ulitzer and Yashphe, 1975). Intracellular CAMP concentrations regulate the synthesis of many inducible enzymes, including the luciferase of a marine luminous bacteria (Nealson et al., 1972), by controlling mRNA transcription (Pastan and Adhya, 1976). Many of these are sugar catabolizing enzymes which are unneeded in the presence of glucose and are therefore repressed by it (catabolite repression). Exogenous CAMP added to the medium overcomes this repression.
Thus the intracellular cAMP level is carefully adjusted to the nutritional status of the cell and the need for catabolic enzyme synthesis. The intracellular CAMP concentration of cAMP increases as CAMP is synthesized from ATP via adenylate cyclase and can be decreased by hydrolysis by cAMP phosphodiesterase and in some cases by active export from the cell (Pastan and Adhya, 1976; Saier et al., 1975). Uptake of CAMP has been studied by only a few investigators (Lefebvre et al., 1978; Goldenbaum and Hall, 1979), and even then only at high ( $m M$ ) concentrations. Uptake of cAMP from the environment has not so far been shown to be a mechanism for increasing the intracellular CAMP concentration in bacteria; thus uptake of CAMP by marine bacteria could be a unique adaptation to life in a low nutrient environment. To contribute to the intracellular pool, however, marine bacteria must specifically take up intact CAMP (not hydrolysis products) from concentrations around $10^{-11} \mathrm{M}$, at significant rates.

DCAMP was taken up by natural bacterial populations by specific, energy-dependent, high-affinity transport systems with apparent $K_{\mathrm{m}}$ values of $10^{-11}$ to $10^{-9} \mathrm{M}$. (Details of CAMP transport and metabolism will be reported elsewhere). Uptake was abolished by mercuric chloride (see 'Methods') and carbonyl cyanide m-chlorophenylhydrazone (which dissipates energy for transport), but was unaffected by light. The uptake of DCAMP was highly specific. Thousandfold greater concentrations of structurally related compounds (inorganic phosphate, adenine, adenosine, and $3^{\prime}$ or $5^{\prime}$ adenosine monophosphate [AMP]) had little effect on uptake of $\left(2,8-{ }^{3} \mathrm{H}\right)$-labelled cAMP. In contrast, unlabelled CAMP strongly inhibited uptake and cGMP was nearly as effective, suggesting the importance of cyclic structure for uptake. The specificity of uptake varied somewhat due to population differences and was the highest at tracer CAMP concentrations.

Two lines of evidence show that CAMP is taken up intact rather than as hydrolysis products. First, $\left({ }^{32} \mathrm{P}\right)$ CAMP was taken up as well as $\left(2,8-{ }^{3} \mathrm{H}\right)$-CAMP, both in the presence and absence of large $\left(>10^{4}\right)$ excesses of unlabelled 5'AMP or inorganic phosphate. If the phosphorus label had been cleaved or the labelled compound hydrolyzed to 5'AMP, before uptake, then unlabelled inorganic phosphate or 5' AMP should have abolished $\left({ }^{32} \mathrm{P}\right)$ uptake. The second indication of uptake of intact cAMP is that $\left({ }^{32} \mathrm{P}\right)$-cAMP could be recovered from cell extracts after uptake. The radioactive CAMP extracted was identified by its comigration with authentic CAMP by thin layer chromatography and by its hydrolysis with $3^{\prime}, 5^{\prime}$-cyclic nucleotide phosphodiesterase.

The intracellular cAMP concentrations in Escherichia coli and other procaryotes are about $1 \mu \mathrm{M}$ (Pas- 
tan and Adhya, 1976). A calculation based on measured DCAMP uptake rates from seawater showed that uptake could significantly increase the intracellular cAMP levels in marine bacteria. For a bacterial cell of $0.1 \mu \mathrm{m}^{3}$ volume (Fuhrman and Azam, 1980) and uptake rates between 1.28 and $28.19 \times 10^{-23}$ mol cell ${ }^{-1} \mathrm{~h}^{-1}$ (Fig. 2a), intracellular cAMP concentration could increase by 0.13 to $2.82 \mu \mathrm{M} \mathrm{h}^{-1}$. Thus, large transient increases in cellular cAMP could occur in a few minutes in marine bacteria, which grow relatively slowly (i.e. with a doubling time of about 1 d) (Fuhrman and Azam, 1980).

In conclusion, DcAMP occurs in seawater in concentrations reflecting a dynamic balance of production and utilization by marine organisms. Likely mechanisms of input are active excretion by marine organisms and loss of their metabolic pools due to predation. Finally, DcAMP removal from seawater by marine bacteria may represent a novel mechanism for increasing their intracellular cAMP concentration, and thus regulating their metabolism.

Acknowledgements. We thank R. E. Hodson for initial work on occurrence of DcAMP, J. A. Fuhrman and J. T. Hollibaugh for counting bacteria, J. Stearns and D. Osborn for help in manuscript preparation, and G. A. Jackson for critical review. This work was supported by US Department of Energy Contract DE-AMO3-76SF00010 and National Science Foundation Grant OCE77-26400 CEPEX.

\section{LITERATURE CITED}

Azam, F., Hodson, R. E. (1977). Dissolved ATP in the sea and its utilization by marine bacteria. Nature, Lond. 267 : 696-698

Azam, F., Hodson, R. E. (1977). Size distribution and activity of marine microheterotrophs. Limnol. Oceanogr. 22: $492-501$

Azam, F, Holm-Hansen, O. (1973). Use of tritiated substrates in the study of heterotrophy in seawater. Mar Biol. 23: $191-196$

Butcher, R. W. (1974). Cyclic 3', 5'-nucleotide phosphodiesterase from bovine heart. In: Hardman, J. G., O'Malley, B. W (eds) Cyclic nucleotides. Meth. Enzym., Vol. 38, Academic Press, New York, pp. 218-223

Daumas, R. A., Saliot, A. (1977). The inventory of marine organic chemistry. Mar. Chem. 5: 417-427

Francko, D. A., Wetzel, R. G. (1980). Cyclic AMP: Seasonal variations in two lakes and potential ecological significance. Abstr. Papers A. Meet. Am. Soc. Limnol. Oceanogr.

Fuhrman, J. A., Ammerman, J. W., Azam, F. (1980). Bacterioplankton in the coastal euphotic zone: Distribution, activity and possible relationships with phytoplankton. Mar. Biol. 60: 201-207

Fuhrman, J. A., Azam, F. (1980). Bacterioplankton secondary production estimates for coastal waters of British Columbia, Antarctica, and California. Appl. environ. Microbiol. 39: 1085-1095

Goldenbaum, P. E., Hall, G. A. (1979). Transport of cyclic adenosine 3',5'-monophosphate across Escherichia coli vesicle membranes. J. Bacteriol. 140: 459-467

Hobbie, J. E., Daley, R. J., Jasper, S. (1977). Use of nuclepore filters for counting bacteria by fluorescence microscopy. Appl. environ. Microbiol. 33: 1225-1228

Hodson, R. E., Holm-Hansen, O., Azam, F. (1976). Improved methodology for ATP determination in marine environments. Mar. Biol. 34: 143-149

Hollibaugh, J. T., Carruthers, A. B., Fuhrman, J. A., Azam, F. (1980). Cycling of organic nitrogen in marine plankton communities studied in enclosed water columns. Mar. Biol. 59: 15-21

Holm-Hansen, O. (1973). Determination of total microbial biomass by measurement of adenosine triphosphate. In: Stevenson, L. H., Colwell, R. R. (eds) Estuarine microbial ecology. Univ. of South Carolina Press, Columbia, pp. 73-89

Lefebvre, G., Martin, N., Gay, R. (1978). Periodic cyclic AMP uptake by synchronously grown cells of Nocardia restricta and Arthrobacter globiformis. FEBS Lett. 93: 55-57

Menzel, D. W., Case, J. (1977). Concept and design: Controlled ecosystem pollution experiment. Bull. mar. Sci. 27: 1-7

Mopper, K. (1977). Sugars and uronic acids in sediment and water from the Black Sea and North Sea with emphasis on analytical techniques. Mar. Chem. 5: 585-603

Mopper, K., Dawson, R., Liebezeit, G., Ittekkot, V. (1980). The monosaccharide spectra of natural waters. Mar. Chem. 10: $55-66$

Morris, R. J., Eglinton, G. (1977). Fate and recycling of carbon compounds. Mar. Chem. 5: 559-572

Nealson, K. H., Eberhard, A., Hastings, J. W. (1972). Catabolite repression of bacterial bioluminescence: Functional implications. Proc. natn. Acad. Sci. U.S.A. 69: 1073-1076

Pastan, 1., Adhya, S. (1976). Cyclic adenosine 5'-monophosphate in Escherichia coli. Bact. Rev. 40: 527-551

Pastan, I. H., Johnson, G. S., Anderson, W B. (1975). Role of cyclic nucleotides in growth control. A. Rev. Biochem. 44: 491-522

Rickenberg, H. V. (1974). Cyclic AMP in prokaryotes. A. Rev. Microbiol. 18: 353-369

Saier, M. H., Feucht, B. U., McCaman, M. T. (1975). Regulation of intracellular adenosine cyclic $3^{\prime}: 5^{\prime}$-monophosphate levels in Escherichia coli and Salmonella typhimurium. J. biol. Chem. 250: 7593-7601

Steiner, A. L. (1974). Assay of cyclic nucleotides by radioimmunoassay methods. In: Hardman, J. G., O'Malley, B. W. (eds) Cyclic nucleotides. Meth. Enzym., Vol. 38. Academic Press, New York, pp. 96-105

Ulitzer, S., Yashphe, J. (1975). An adenosine $3^{\prime}, 5^{\prime}$-monophosphate-requiring mutant of luminous bacteria Beneckea harveyi. Biochim. biophys. Acta 404: 321-328

Waterbury, J. B., Watson, S. W., Guillard, R. R. L., Brand, L. E. (1979). Widespread occurrence of a unicellular, marine, planktonic, cyanobacterium. Nature, Lond. 277: 293-294

Williams, P. J. leB. (1975). Biological and chemical aspects of dissolved organic material in sea water. In: Riley, J. P., Skirrow, G. (eds) Chemical oceanography, Vol. 2. Academic Press, London, 2nd ed., pp. 301-363

This paper was presented by Dr. N. D. Holland; it was accepted for printing on January 6, 1981 